\title{
BY WAY OF FRANCE AND BEYOND: JOYCE TRANSLATIONS INTO ITALIAN
}

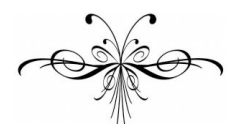

SERENELla ZANOTTI

\section{The French influence: an early anonymous translation}

$\mathrm{J}$ oyce's early Italian reception mostly depended on French translations. ${ }^{1}$ The French influence was most prominent in the case of Ulysses, for the novel remained untranslated until 1960. Like in the rest of Europe, Auguste Morel's version became "an authoritative reference on matters of interpretation", 2 occasionally replacing the original when the book was either unavailable or linguistically inaccessible to the translator.

This is the case with the translated excerpts that appeared in the newspaper L'Ora in 1926. An anonymous note was appended to the translation, also anonymous, claiming that these were "the first extracts" from Joyce's novel "to appear in Italian" (L'Ora 1926, 3). The translator, however, was far from revealing that his/her source text was not in fact the English original, but a French translation of passages from the Calypso, Ithaca and Penelope episodes that had appeared in the first issue of Commerce in $1924 .^{3}$

${ }^{1}$ In Italy Dubliners came to be known as Gente di Dublino, after the French Gens de Dublin, trans. Yva Fernandez, Hénène du Pasquier, Jacques-Paul Reynaud (Paris: Librairie Plon, 1926), and Portrait as Dedalus, after the French Dedalus: Portrait de l'artist jeune par lui-même, trans. Ludmila Savitzky (Paris: Editions de la Sirène, 1924). On the influence of the French translations on Joyce's reception in Europe see Geert Lernout, 'Introduction' and Patrick O'Neill, 'French Joyce: Portrait of an Oeuvre' in The Reception of James Joyce in Europe, vol. I, ed. Geert Lernout and Wim van Mierlo (London: Continuum, 2004), pp. 3-13 and 411-21. Also note Patrick O'Neill, Polyglot Joyce: Fictions of Translation (Toronto: University of Toronto Press, 2005).

2 Jacques Aubert quoted by Patrick O'Neill in 'French Joyce', The Reception of James Joyce in Europe, vol. I, p. 415.

3 James Joyce, Ulysse. Fragments, trans. Valery Larbaud and others, Commerce, I (Summer 1924), pp. 121-58. See Cianci, Giovanni, Violante, Piero and Perriera, Michele, 'Pagine strane di uno stranissimo libro - Frammenti della prima traduzione italiana 
That the anonymous Italian translator was relying on that French version is apparent in the passage with Bloom entering his bed:

with solicitude, the snakespiral springs of the mattress being old, the brass quoits and pendent viper radii loose and tremulous under stress and strain: prudently, as entering a lair or ambush of lust or adder ( $U$ 17.2114-18)

avec solicitude, les ressorts serpentspirales du sommier étant vieux, les disques de cuivre et les pendants rayons reptiliformes desserrés et tremblants à force d'efforts e contre-efforts: avec prudence, comme pour entrer dans une repaire ou dans un guet-apens de luxure et de couleuvres (F/Morel 1924, 152)

con sollecitudine, le molle a spirale del sommier essendo vecchie, i dischetti di cuoio ed i divergenti raggi serpentiformi essendo disserrati e sconnessi a forza di sforzi e controsforzi: con prudenza, come per entrare in un riparo o in una imboscata di lussuriosi colubri (I/L'Ora 3$)$

The Italian translator seems to keep almost literally to the French text, although allowing himself/herself occasional deviations, as in the use of punctuation, which is somewhat domesticated, and at the level of vocabulary.

Most of the selected passages aim at giving a sample of the interior monologue technique. Morel's version of Penelope cleverly tries to reproduce Joyce's disruptive use of punctuation by emphasising the illiterate, oral element of Molly's discourse. Hence the suppression of apostrophes and accents so as to make Molly's orthographical irreverence even more evident than in the original:

I suppose theyre just getting up in China now [...] well soon have the nuns ringing the angelus theyve nobody coming in to spoil their sleep except an odd priest or two for his night office [...] what kind of flowers are those they invented like the stars the wallpaper in Lombard street [...] Fridays an unlucky day first I want to do the place up someway the dust grows in it I think while Im asleep [...] I love the smell of a rich big shop (U 18.1541-54)

jimagine quils se levent en ce moment en Chine [...] bon bientot nous entendrons les soeurs sonner langelus elles nont personne qui vienne deranger le sommeil excepte un prete ou deux pour son office [...] quescequecest que cette espece de fleur quils ont invente comme les

di Ulisse', in L'Ora (5 August 1971), p. 8. The French translation had been literally thrown off by Auguste Morel, with the help of Adrienne Monnier, Sylvia Beach and Larbaud himself after the famous Paris séance of 1921. See John Brown, 'Ulysses into French', Joyce at Texas. Essays on the James Joyce Materials at the Humanities Research Center, ed. Dave Oliphant and Thomas Zigal (Humanities Research Center: The University of Texas at Austin, 1983), pp. 29-60, p. 37. 
etoiles le papier de tenture de Lombard street [...] le vendredi est un mauvais jour je veux arranger la maison la poussiere y pousse je crois pendant que je dors [...] jaime lodeur dune belle et grande boutique (F/Morel 1924, 155-6)

Quite interestingly, the number of word agglutinations and suppressed apostrophes increases in the Italian version:

mimmagino chessi si alzano in questo momento in Cina [...] bene presto sentiremo le suore suonare langelus esse nhanno nessuno che viene disturbare il sonno tranne un prete o due per luffici $[. .$.$] checosè questa$ specie di fiori chessi inventano come le stelle la carta di tintura di lombardstreet $[\ldots]$ il venerdi è un cattivo giorno io voglio mettere in ordine la casa ecacciarne la polvere credo durante che io dormo no no $[\ldots]$ amo lodore duna grande e bella bottega (I/L'Ora 3)

But unlike in the French text, accented words are maintained in Italian. On the whole, the Italian translator seems to be following its French source very closely, although a few orthographical innovations occur (lombardstreet, luffici, and ecacciarne) that reveal a relative autonomy. Improper literal translation, however, may produce syntactic oddity, so while pendant que je dors is standard French, durante che io dormo sounds terribly odd in Italian.

Translating from a translated text is a hazardous operation likely to open up the way to pedestrian errors. The Italian translator, for instance, ends up, surprisingly, turning Stephen - the visitor Molly is so excited about - into a lady:

in case he brings him home tomorrow today I mean no no ... I can accompany him (U 18.1048-52)

au cas ou il lemmenerait demain je veux dire aujourd'hui non non ... je peux laccompagner (F/Morel 1924, 155-6)

nel caso egli la conducesse domani voglio dire oggi no no ... io posso accompagnarla (I/L'Ora 3$)$

Thus Italian Molly's excitement about a supposed female friend that Bloom is about to bring home sounds quite disconcerting to us. One may call this a misinterpretation, but it may well be, quite simply, the result of a censorious treatment of Joyce's work, or a more likely effect of prudery. The selection of the passages seems itself to respond to a principle of prudery. Bloom is dismissed as he enters the bed, while the catalogue of Molly's lovers and her erotic fantasies are simply left out.

Misinterpretations proliferate particularly in the novel's closing passage, as illustrated by the following example: 
and Gibraltar as a girl where I was a Flower of the mountain (U 18.1601-2)

et Gibraltar quand jetais jeune fille ou jetais une fleur de la montagne (F/Morel 1924, 158)

e Gibilterra quando ero giovinetta o ero un fiore della montagna (I/L’Ora 3)

Here, the original where, rendered in French as ou, becomes $o$ 'or', due to the ambiguity of the French word, both adverb and conjunction: an error that would have hardly occurred had the Italian translator checked his source text against the original. If translated back, the passage ends up reading, quite oddly, as "when I was a girl I either was a Flower of the mountain or I put the rose in my hair". But the point where the Italian translation is more deviating from the English original is the closing line ("and yes I said yes I will Yes" $U$ 18.1608-9), where a literal rendering of the French je veux bien > voglio bene transforms Molly's affirmative I will into an unexpected and unusual I love, which does not make any sense.

Though probably involuntary, the effect is, again, quite flattening, if not prudish, as the whole selection is. All the 'incriminating' passages of the chapter are carefully avoided, all sexual allusions censored. On the whole, this Italianized Molly has very little of the humorous, uninhibited personality of Joyce's character.

\section{Following from a distance: Alberto Rossi}

Ulysses became more accessible around 1930. Soon after the appearance of the much-revered French translation, Stuart Gilbert's equally influential book on Ulysses was finally published. These were both presented as "authorized" texts, with Joyce consulted "on every doubtful point". The former implicitly offered itself as a model for the translations to come, the latter as the novel's official interpretation.

With these books at hand, Alberto Rossi set to translating "Telemachus" (I/Rossi 1931) and "Proteus" (I/Rossi 1949). As I have argued elsewhere, ${ }^{5}$ Rossi had Ezra Pound help him with the translation. He worked from the English original but also consulted the French translation every now and then. There are a number of passages merely adapted from the French text (e.g. "On a field tenney a buck, trippant, proper, unattired"

\footnotetext{
${ }^{4}$ Stuart Gilbert, James Joyce's Ulysses: A Study (New York: Vintage Books, 1955), p. VII.

${ }^{5}$ Serenella Zanotti, 'Pound, Linati, and the Early Italian Translations of Ulysses', in Joyce and/in Translation, ed. Rosa Maria Bollettieri Bosinelli and Ira Torresi (Rome: Bulzoni, 2007), pp. 53-75.
} 
U $3.337 \rightarrow$ "D'orangé un cerf passant, au naturel, sans massacre" $\mathrm{F} /$ Morel $48 \rightarrow$ "In campo arancio un daino, passante, in naturale, senza massacro" I/Rossi 1949, 87), although Rossi handles Morel's version with great care and more often than not he chooses a different solution. He often relies on the French translation in dealing with quotations, as is the case with the Middle English "Agenbite of inwit" $(U$ 1.481) $\rightarrow$ "Morsure de l'ensoi" (F/Morel 19) $\rightarrow$ "Morsura dell'io fondo" (I/Rossi 1931, 493). Also suggested by Morel is the rendering of the opening adjectival pair "Stately, plump" $\rightarrow$ "Majestueux et dodu" (F/Morel 7) $\rightarrow$ "Maestoso e paffuto" (I/Rossi 1931, 476).

In most instances, however, Rossi dissociated from (and even emended) the French text, as in translating Buck Mulligan's Nietzschean epithet hyperborean ("I'm hyperborean as much as you"). The reference to the Übermensch (Gifford 1989, 15) gets lost in the French version ("Je suis un animal à sang froid" F/Morel 9), which brings to the surface the immediate semantic content. Rossi (1931) reestablished the Nietzschean allusion ("Sono anch'io iperboreo" 479) to the detriment of clarity, according to Joyce's intention. He also toned down the rather vulgar overtones that Mulligan's speech had acquired in French, as in the following examples: "Where's the sugar? O, jay, there's no milk" $(U 1.336) \rightarrow$ "Ah, putain, il n'y a pas de lait" (F/Morel 16) $\neq$ "O, malora, non c'è latte" (I/Rossi 1931, 488); "O, damn you and your Paris fads" $\rightarrow$ "Merde pour vous et vos poses de Paris" (F/Morel 16) $\neq$ "O va all'inferno, te e le tue fisime parigine" (I/Rossi 1931, 488); "Ah, go to God, Buck Mulligan said" $\rightarrow$ "Ah, merde!" (F/Morel 25) $\neq$ "Bene, vada con Dio" (I/Rossi 1931, 501).

Rossi presented his translation as different in tone and meaning and overtly questioned the authority of the French Ulysses, the "errors and inaccuracy" of which suggested that authorial supervision had been less attentive than it was assumed (I/Rossi 1949, 59).

\section{Beyond Ulysse: Giulio De Angelis}

The first integral Italian translation of Ulysses was published as late as October 1960. Carefully crafted by Giulio De Angelis, this version is still considered a monument of philological accuracy and creativity. ${ }^{6}$ Released over thirty years after the official French translation, it had a

\footnotetext{
${ }^{6}$ It should be recalled, here, that the translation benefited from the editorship of a group of scholars including Giorgio Melchiori, who meticulously went over the typescript version in the year previous to its publication. See Giorgio Melchiori 'Joyce Studies in Italy' in The Benstock Library as a Mirror of Joyce, ed. Rosa Maria Bollettieri Bosinelli and Franca Ruggieri (Rome: Bulzoni, 2002), pp. 15-20.
} 
substantial body of critical work to count on as well as a number of translations in other languages to help.

Though still a point of reference for De Angelis, the French version came to be gradually left behind. Indeed his Italian version often succeeds where the French one fails, as in the rendering of the opening sentence in Calypso: "Mr Leopold Bloom ate with relish the inner organs of beasts and fowls" $\rightarrow$ Mr. Leopold Bloom se nourrissait avec délectation des organes internes des mammifères et des oiseaux (F/Morel 54) $\neq$ "Mr Leopold Bloom mangiava con gran gusto le interiora di animali e di volatili" (I/De Angelis 1960, 55). In translating "Kidneys were in his mind" ( $U$ 4.6), De Angelis got the irony in the preposition in instead of on and translated, accordingly, "I rognoni erano nel suo pensiero" (I/De Angelis 1960, 55), where the unidiomaticity of the sentence is equally stressed. ${ }^{7}$

De Angelis worked with an amount of bibliographical material at hand. He was well aware of the subtleties of Joyce's style and paid great attention to verbal and thematic recurrence, as also indicated by the translation's surviving manuscripts. ${ }^{8}$ A revealing example can be drawn from "Telemachus" and "Proteus", of which other Italian translations exist: the already mentioned Rossi 1931 and 1949, as well as Bona Flecchia’s 1995 version. ${ }^{9}$ I shall confine my discussion to a few indicative cases.

\section{buck}

Third in order of appearance, the word buck is central to the economy of the opening chapter. A character's name (Buck Mulligan), it is also a recurrent thematic element in "Proteus". In the two chapters, Joyce explores the whole realm of the word's semantics. In a transferred sense, it applies to "a gay, dashing fellow; a dandy, fop, 'fast' man" $(O E D)$, which is exactly what Mulligan is. But the word primarily refers to animals. According to the $O E D$, buck is the one outcome of two Old

\footnotetext{
${ }^{7}$ I do not agree with Parks, who finds the translation of this passage flattening. See Tim Parks, Translating Style. The English Modernists and Their Italian Translations (London and Washington: Cassel, 1998), p. 77.

${ }^{8}$ Anna Maria Aiazzi, 'Il farsi di una traduzione memorabile: 1'Ulisse di Joyce nel fondo Giulio de Angelis' in Letterature d'Europa e d'America. On line at: http://www.unifi.it/rivlea/upload/sub/LEA0_110505/Il_farsi_di_una_traduzione_memo rabile.pdf (accesses May 8, 2008), pp. 349-50.

9 James Joyce, Ulisse, trans. Bona Flecchia (Firenze: Shakespeare and Company, 1995). For a study of this translation see Rosa Maria Bollettieri Bosinelli, 'Who Is She When She Is Not at Home? Molly's Journey Through the Italian Language and Culture', in A Collideorscape of Joyce. Festschrift For Fritz Sen, ed. Ruth Frehner and Ursula Zeller (Dublin: The Lilliput Press, 1998), pp. 444-460.
} 
English words: buc and bucca. The former was used for the male deer, the latter for the he-goat. As a verb too buck displays a number of meanings: "to leap vertically from the ground, drawing the feet together like a deer, and arching the back"; "to butt"; but also "to copulate" $(O E D)$. The translators must have had a hard time sorting out meaning, since all of the semantic variants of the word occur in the translations under scrutiny.

Mulligan's glossing of his own name ("Tripping and sunny like the buck himself" $U$ 1.42) leaves no doubt as to what it indicates: certainly an animal, either deer or goat. The translators opted almost unanimously for deer, except for De Angelis, who eloquently changed the original translated term ('pricket') into 'he-goat' in the revised 1988 edition:

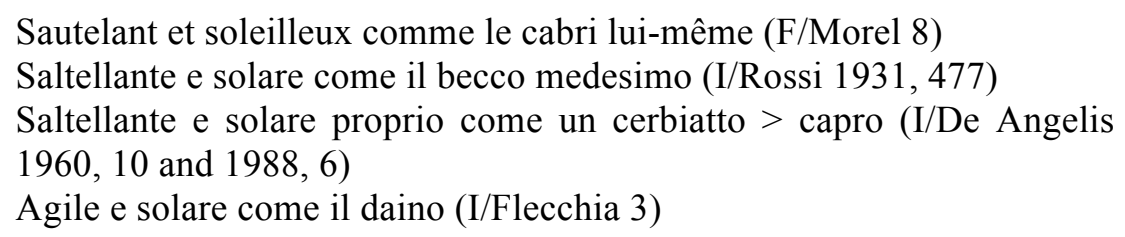

The he-goat option accounts for the strong sexual connotation of the word in "Telemachus", which is made even clearer by Mulligan's remark: "Redheaded women buck like goats" $\left(U\right.$ 1.706) ${ }^{10}$ In this case, the French translation tends to be quite euphemistic, as opposed to the Italian wordings, which are more or less explicit:

Les rousses font ça [do it] comme des chèvres (F/Morel 25)

Le donne rosse zompano [leap/copulate] come capre (I/Rossi 1931, 501)

Le rosse di pelo cozzano [butt/copulate] come capre (I/De Angelis 1960, 34)

Le rosse scopano [fuck] come capre (I/Flecchia 18)

A different semantic range is displayed in "Proteus". In the first instance, buck collocates with lodgers: "madame in rue Git-le-Coeur, canary and two buck lodgers" (U 3.254).

un canari et deux pensionnaires un peu là (F/Morel 46)

con il canarino e due pensionanti in gamba (I/Rossi 1949, 87)

canarino e due caproni pensionanti (I/De Angelis 1960, 64)

con il suo canarino a rue Gît-le-Coeur e due caproni per pensionanti

(I/Flecchia 34)

\footnotetext{
${ }^{10}$ Similarly, Jacques Aubert (in Joyce, Oeuvres, p. 1058) suggests 'bouquetin' instead of 'cabri', which translates the strong sexual connotations of buck quite imperfectly. See also Carlo Bigazzi 'Imago canis nella Telemachia' in Joyce Studies in Italy 2, ed. Carla De Petris (Rome: Bulzoni, 1988), pp. 137-47.
} 
The translations diverge sensibly, ranging from 'boring' (Morel) 'clever' (Rossi), and 'uncouth, boorish' (De Angelis, Flecchia). The latter ones manage to preserve the goat image, for caprone may apply to both animal and man. The image of the buck also occurs to Stephen when picturing the dog trotting on the sand: "On a field tenney a buck, trippant, proper, unattired" (U 3.337). It is noteworthy that here the word co-occurs with trippant, which may also be an implicit reference to $U 1.42$. Here the translators unanimously read buck as deer:

D'orangé un cerf passant (F/Morel 48)

In campo arancio un daino, passante (I/Rossi 1949, 87)

In campo scuro un cerbiatto, saltante (I/De Angelis 1960, 67)

Cerbiatto in campo scuro, saltellante (I/Flecchia 36)

In one case only does buck refer to Mulligan: "his broadtoed boots, a buck's castoffs, nebeneinander" (U 3.446). Morel translates it as 'dandy' and Rossi follows him closely, whereas De Angelis sticks to 'deer' even in the revised edition, forgetful of his own previous correction, whereby Joyce's intra-textual reference becomes opaque:

Laissés-pour-compte nebeneinander d'un copain chic (F/Morel 51)

gli smessi nebeneinander di un gagà (I/Rossi 105)

scarti di un cerbiatto, nebeneinander (I/ De Angelis 1960, 71)

scarti di una cerbiatto, nebeneinander (I/Flecchia 39)

\section{kip}

Recurrent slang words punctuate Mulligan's speech, resounding as a sort of linguistic leitmotif throughout the chapter. Consistency should be the norm in translating recurrent features, all the more so when they contribute to characterization. De Angelis seems to make a point of faithfully reproducing Mulligan's linguistic tic, whereas the other translators seem to be more concerned with recreating the slangish tone of the original than verbal repetition. One case in point is the word kip (slang for 'brothel'), a trademark of Mulligan's:

The school kip? (U 1.293)

La braise de la boite? (F/Morel 14)

Che, i baiocchi della scuola? (I/Rossi 1931, 486)

Quel casino di scuola? (I/De Angelis 1960, 19)

Quella galea di una scuola? (I/Flecchia 9) 
What sort of a kip is this? (U 1.339)

En voilà un boxon (F/Morel 16)

Che razza di baracca è questa? (I/Rossi 1931, 488)

Che casino è questo? (I/De Angelis 1960, 21)

Che tana è mai questa? (I/Flecchia 10)

Hurry out to your school kip (U 1.339)

Cavalez jusqu'à votre bordel d'école (F/Morel 19)

Corri a quel tuo bordello di scuola (I/Rossi 1931, 492)

Fa una corsa a quel casino della tua scuola (I/De Angelis 1960, 26)

Muoviti, vai a quella tana d'una scuola (I/Flecchia 13)

Let us get out of the kip (U 1.466)

Il faut que nous nous démerdions (F/Morel 20)

Usciamo fuori da codesto bordello (I/Rossi 1931, 494)

Usciamo da questo casino (I/De Angelis 1960, 27)

Battiamocela da questa trappola (I/Flecchia 13)

This aspect seems to have been overlooked by Morel, Rossi and Flecchia, who tend to intense verbal variation. However, De Angelis' calculated consistency in translating Mulligan's speeches helps create the effect of a strongly characterised idiolect.

\section{dogsbody}

The problem for the translator here is twofold: 1 . rewording the humorous, almost sarcastic colloquialism; 2. dealing with a metaphor that soon becomes reality. It is Mulligan who first addresses Stephen as "poor dogsbody" with reference to his indigence: "- Ah, poor dogsbody, he said in a kind voice. I must give you a shirt and a few noserags" ( $U$ 1.112-3). Then Stephen accepts the epithet for himself when peering "at the mirror held out to him": "Who chose this face for me? This dogsbody to rid of vermin. It asks me too" ( $U$ 1.135-7).

The word gradates from the metaphorical to the literal to the psychic symbolic, the image of the dead dog gradually coming to the fore and preparing "the reader for the dog's body on the strand in "Proteus"" (Benstock 1974, 5). ${ }^{11}$ Translators basically seem to have two options at their disposal: either translate the compound verbatim (Morel, De Angelis) or almost verbatim (Rossi) in order to preserve the dog image; or transpose its metaphorical meaning (Flecchia). With the exception of De

${ }^{11}$ Bernard Benstock, "Telemachus", in James Joyce's Ulysses: Critical Essays, ed. Clive Hart and David Hayman (Berkeley and Los Angeles: University of California Press, 1974), pp. 1-16. U 3.348-52. The expression resurfaces in "“Circe"”, in a ferocious line pronounced by Mulligan. The passage has been restored by Gabler as "Kinch dogsbody killed her bitchbody" (15.4178-9). 
Angelis, who uses the same translated expression consistently and preserves the internal reference, the tendency is one of extreme variation:

poor dogsbody (U 1.112)

pauvre corps de chien (F/Morel 10)

povero cane di nessuno (I/Rossi 1931, 480)

povero corpo d'un cane (I/De Angelis 1960, 13)

povero rifiuto della società (I/Flecchia 5$)$

This dogsbody to rid of vermin (U 1.137)

Ce museau de chien qui a besoin d'être épouillé (F/Morel 10)

Questo povero cane di un corpo da ripulire dai vermi (I/Rossi 1931, 481)

Questo corpo d'un cane da spidocchiare (I/De Angelis 1960,14)

Questo corpo di carogna da sverminarsi (I/Flecchia 6)

Ah, poor dogsbody. Here lies poor dogsbody's body (U 3.351-2)

Ah, pauvre peau-de-chien. Ci-gît la peau du pauvre peau-de-chien (F/Morel 48)

Oh, povero corpoduncane. Qui giace il corpo di un povero corpoduncane (I/Rossi 1949, 95)

Ah, povero corpo d'un cane. Qui giace il corpo d'un povero corpodicane (I/De Angelis 1960, 68)

Ah, povero corpo di cane. Qui giace il corpo del povero corpodicane ((I/Flecchia 36)

Among other things, this example highlights the importance of coherence in translation as a means of enabling readers to grasp connections between chapters.

\section{fearful jesuit}

As Fritz Senn has argued, translations make "[s]emantic and contextual divarications" more apparent. ${ }^{12}$ This is the case with Mulligan's mocking appellation of Stephen as fearful jesuit in "Telemachus":

Halted, he peered down the dark winding stairs and called up coarsely:

- Come up, Kinch. Come up, you fearful jesuit (U 1.8)

Gifford (13) recalls that the Jesuits "were noted for their uncompromising intellectual rigor (and hence were popularly regarded as "fearful" in their seriousness)". The phrase has also been interpreted as an echo of Friar Lawrence's words to Romeo in Shakespeare's drama: "Romeo, come forth, thou fearful man / Affliction is enamoured of thy parts / And

12 Fritz Senn, 'Dynamic Adjustments in Dubliners', in New Perspectives on Dubliners, ed. Mary Power and Ulrich Schneider (Amsterdam: Rodopi, 1997, pp. 1-18), p. 7. 
thou are wedded to calamity" (Romeo and Juliet III.iii.1), ${ }^{13}$ where fearful means 'frightened, timorous' rather than 'inspiring terror' (OED). This semantic ambivalence fits well with the ambiguity of the StephenMulligan relationship, but it is hardly transposable in translation. Translators have to make choices:

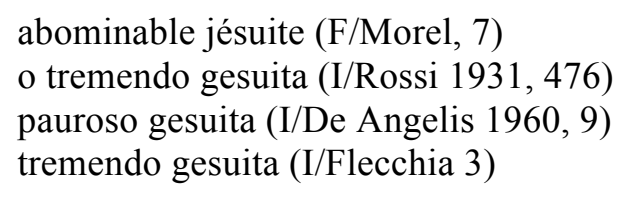

Remarkably, De Angelis is the only one who echoes the Shakespearian quote. The consistency and philological precision of his translation made it an indisputable model for the next generation of Joyce translators.

\section{The French Ulysses no longer a model: Bona Flecchia}

When 25-year-old Bona Flecchia set to work on a new Italian translation of Ulysses in the early 1990s, Morel's version appeared irremediably outdated (a new French translation was to come out in 2004). In fact, there is strong textual evidence that Flecchia had instead used De Angelis as a model and constant reference. Compared to her predecessor, however, she seems less accurate, though often quite effective and original.

Understandably, the translation was praised for linguistic invention rather than for philological accuracy, as apparent in the wording of the opening sentence of Calypso: "Mr Leopold Bloom mangiava con trasporto le interiora di quadrupedi e volatili" (I/Flecchia 43). This is, in its own way, an amelioration in tone of De Angelis's hybrid rendering of the biblical "beasts and fowls" ( $\rightarrow$ "di animali e di volatili"), that combines the broad, unmarked animali with the more specific, almost technical volatili. Flecchia's "quadrupedi e volatili" reestablishes semantic balance by rewording beasts as 'quadrupeds'. In so doing, she succeeds in reproducing the narrator's ironic tone, though drawing from a different register.

What Flecchia's version lacks is consistency, as shown by the instances analysed in the previous section. She seems to neglect the relevance of verbal recurrence in Joyce's writing, unlike De Angelis, who is very accurate in handling it. In this respect, Flecchia's variable approach to the Old English quote "Agenbite of inwit" is quite remarkable. Follow-

13 See Weldon Thornton, Allusions in Ulysses (University of North Carolina Press: Chapel Hill, 1968), p. 11. 
ing the 1922 text, where the line is mentioned twice, she first elaborates as "Morso dalla coscienza" (13), 'remorsed, bit by conscience', and then as "Rimorso alla coscienza" (14), an unusual datival form for "remorse in the conscience'. De Angelis adopts a totally different strategy by repeating the untranslated phrase.

Despite its many faults, Flecchia's version stands out for poetic inventiveness, as when translating jejune jesuit $(U 1.45)$ an alliterative play on words typical of Mulligan. An expression of disapproval, jejune applies to either physical ('deficient or lacking in nourishment, thin') or mental qualities ('dull, flat, bald, dry', but also 'lacking knowledge or experience; juvenile, immature, childish'). The point here is whether or not to give priority to sound:

Vorrai poi partire? Giuggiolone d'un gesuita! (I/Rossi 1931, 478)

Verrà lo sparuto gesuita? (I/De Angelis 1960, 10)

Verrebbe il giunco gesuita? (I/Flecchia 4)

Rossi alliteratively translates as 'simpleton', while De Angelis chooses the adjective 'gaunt', thus losing the sound pattern. Only Flecchia dares an unusual poetic image ('rush'), her intended strategy being to stress alliteration.

Flecchia's attempt to move away from her authoritative predecessor, who nonetheless remains a model, is manifest. Her rendering of Mulligan's qualification of Haines as a ponderous Saxon ("- God, isn't he dreadful? he said frankly. A ponderous Saxon. He thinks you're not a gentleman" $U$ 1.151) is a case in point. Haines the "ponderous Saxon" evidently opposes to Stephen the "jejune jesuit". Meaning both 'heavy' and 'weighty, serious', ponderous is the counterpart of jejune. Haines is indeed a conceited bore and Stephen's intellectual inferior. This idea of heaviness is clearly expressed in Morel's, Rossi's and De Angelis's wordings:

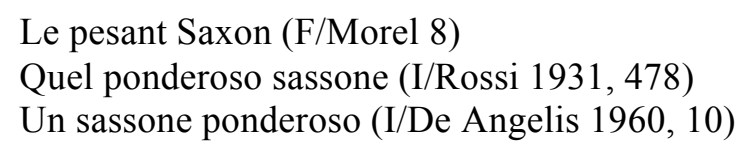

Flecchia differs sensibly. She drops the ponderously Latinized adjective in favour of a homosyllabic participle: "Un sassone ponderante" (I/Flecchia 4). In this way, ponderous Haines becomes a pondering man, Mulligan's sarcastic remark being somewhat defused.

Flecchia's translating approach is apparent in the rendering of the novel's opening sentence: "Stately, plump Buck Mulligan" (U 1.1). The difficulty here originates from grammatical interpretation, for stately is 
readable as both an adverb and an adjective. ${ }^{14}$ As it is, English readers are likely to regard it as an attributive, though the opening of line 9 ("Solemn$l y$ he came forward") may suggest some kind of parallelism. Certainly syntax contributes to the mocking solemnity of the scene, there being a series of parallel structures signalling elevated style ("Halted, he peered down"). On the other hand, however, the juxtaposition of stately and plump is in train with Joyce's use of adjectival pairs throughout the chapter, especially when the qualified is or has to do with Buck Mulligan ("light untonsured hair", "even white teeth", "plump shadowed face", "sullen oval jowl", "great searching eyes", "smokeblue mobile eyes", etc.).

No univocal answer can be drawn from the supervised German and French translations, the former opening with an adverb ("Gravitätisch kam der dicke Buck Mulligan"), ${ }^{15}$ the latter with an adjectival pair ("Majestueux et dodu" F/Morel 7). The earlier Italian translators accepted the French, with Rossi translating verbatim ("Maestoso e paffuto", 476) and De Angelis following the original juxtaposed pattern ("Solenne, paffuto", 9). Quite surprisingly, Flecchia differs from her predecessors as if accepting Goyert's wording instead: "Maestosamente, quel grassoccio di Buck Mulligan" (I/Flecchia 3). It is hard to say whether Flecchia's evocation of Goyert was intentional. But given the prominence of the passage, she might have meant to signal a radical break with Italian tradition in translating Ulysses.

Illuminating or erroneous as it may be, the 1995 Italian Ulysses seems to confirm Fritz Senn's fruitful intuition that "[e]very tiny part of a Joyce translation has its storytale to tell, it is a comment on the original text, a suggestion of what it might mean". ${ }^{16}$ For translations, even the less accurate ones, help cast light on the original and keep it alive.

Serenella Zanotti serenellazanotti@libero.it Università per Stranieri, Siena

\footnotetext{
${ }^{14}$ See Jack Dalton, “'Stately, plump Buck Mulligan” in Djoytsch', in JJQ, 4 (Summer 1967), p. 207 and Leo Knuth, 'How Stately was Plump Buck Mulligan?' JJQ, 7 (Spring 1970), pp. 204-9.

15 James Joyce, Ulysses, trans. Georg Goyert, Zurich: Rhein-Verlag, 1927.

${ }^{16}$ Fritz Senn, 'The Issue is Translation', JJQ 4 (Spring 1967), p. 164.
} 